\title{
ANALISA PARAMETRIK PENEMPATAN FIN BURITAN PADA SPEED BOAT DI MALUKU
}

\author{
E. R. de Fretes ${ }^{1}$ \\ ${ }^{1} \mathrm{~J} J u r u s a n$ Teknik Perkapalan Fakultas Teknik Universitas Pattimura, Ambon 97234 \\ defretesera@gmail.com
}

\begin{abstract}
Abstrak . Kapal speed boat merupakan kategori kapal cepat yang mempunyai kecepatan dinas yang tinggi, ini ditandai dengan Froude Number (Fn) yang lebih besar dari 1.2. Dalam pengoperasiannya speed boat mempunyai permasalahan yang sangat kruisal tentang trim, dimana pada kondisi kapal kosong sering kali mengalami trim buritan sehingga nahkoda tidak dapat melihat ke depan, untuk itu inovasi penambahan fin buritan di aplikasikan pada kapal speed boat. Penelitian ini bertujuan untuk mendapatkan parameter-parameter dan sudut trim yang mendekati even keel dengan memvariasikan sudut fin buritan dan luas serta lokasi secara vertikal dengan menggunakan uji laboratorium pada laboratorium towing tank Fakultas Teknik. Kondisi trim diperoleh dengan menggunakan camera sport setelah itu dilakukan pengukuran trim dengan menggunakan program autocad. Penelitian ini mendapatkan ukuran Fin yang sesuai adalah $0,36 \mathrm{~m}^{2}$ dan lokasi Fin buritan trim yang sesuai untuk kebutuhan speed boat adalah pada bagian samping buritan dengan posisi titik 0 dari transom bawah searah kemiringan transom, dengan sudut ideal yang digunakan adalah $6^{0}$ terhadap bidang datar sesuai dengan posisi transom
\end{abstract}

Kata kunci: speed boat, Fin buritan, even keel, trim

\begin{abstract}
Times New Roman, 11 pt, Bold]. Speed boat is a fast boat category that has high service speed, this is marked by Froude Number (Fn) which is greater than 1.2. In operating the speed boat has a very critical problem regarding the trim, where the empty ship conditions often experience stern trim so that the captain cannot look forward, for that innovation the addition of the stern fin is applied to the speed boat. This study aims to obtain parameters and trim angles close to the keel event by varying the angle of the stern fin and area and location vertically using laboratory tests in the Engineering Faculty towing tank laboratory. Trim conditions are obtained using a sports camera after which trim measurements are carried out using the Auto CAD program. This study found that the appropriate Fin size was $0.36 \mathrm{~m} 2$ and the fin stern trim location suitable for the speed boat was on the side of the stern with the position of point 0 of the bottom transom in the direction of the transom, with the ideal angle used was 60 against the flat plane according with transom position
\end{abstract}

Keywords: speed boat, stern fin, even keel, trim

\section{PENDAHULUAN}

Kapal speed boat merupakan kategori kapal cepat yang mempunyai kecepatan dinas lebih yang digunakan oleh petugas dalam rangka memberikan pertolongan bila terjadi kecelakaan / musibah, dan atau inspeksi/pemeriksaan di alur pantai, sungai, danau dan penyeberangan [1]. Dalam pengoperasiannya speed boat mempunyai permasalahan yang sangat kruisal tentang trim, dimana pada kondisi kapal kosong sering kali mengalami trim buritan sehingga nahkoda tidak dapat melihat ke depan, adanya hambatan yang besar diakibatkan karena daerah luasan permukaan dan aliran yang terjadi mempunyai titik staknasi yang besar [2] dan [3] serta arah kemudi yang sulit dikemudikan diakibatkan terjadinya lift sehingga luas permukaan basah jadi kecil [4]. Selain itu pada saat mulai berjalan speed boat mempunyai kecenderungan menukik ke haluan [5].

Berdasarkan hasil survey yang dilakukan, kecepatan speedboat lintasan kota jawa-pantai mardika mempunyai kecepatan kapal pada pemuatan penuh yakni 12 knot $(\mathrm{Fn}=0,742)$ dan pada kapal kosong 16 knot $(F n=0,989)$. Dengan 
adanya penambahan Fin tersebut akan menimbulkan gaya angkat yang akan mempengaruhi hambatan kapal sehingga dapat mengatasi trim. yang lebih besar sehingga dalam pengoperasian suatu kapal sering terjadi kecepatan yang diinginkan sering tidak sesuai dengan perencanaan atau daya mesin yang terpasang kadang terlalu besar. Kapal merupakan benda yang komplek dan rumit, dikarenakan kapal bergerak dengan kecepatan tertentu melalui air, baik diatas, melayang maupun di bawah permukaan air. Hal ini menyebabkan kapal mengalami gaya hambat (resistance) oleh air. Oleh karena itu kapal membutuhkan energi tertentu untuk dapat melawan tahanan tersebut. Besar kecilnya tahanan tergantung akan kecepatan dari kapal. Dengan mengurangi tahanan yang di alami kapal maka akan berpengaruh dalam pemakaian energi.selain itu ketika kapal melaju dengan kecepatan tinggi, maka timbul gaya lift yang seakan-akan mengangkat kapal ke atas, jika penempatan muatan yang keliru ataupun pada saat kapal kosong, maka trim kapal tidak dapat dikontrol. Untuk dapat mengontrol trim tersebut, maka salah satu alternatif adalah penambahan Fin buritan yang mampu mempengaruhi gaya lift sehingga trim kapal dapat dikontrol. Penelitian ini bertujuan untuk mengatahui ukuran fin buritan dan sudut fin yang optimal serta posisi dari fin pada bagian buritan speed boat.

\section{KAJIAN DAN METODE}

Metode yang digunakan dalam penelitian ini adalah studi eksperimental, dengan membuat model dari speed boat yang beroperasi dengan terlebih dahulu menggambar rencana garis dengan skala yang telah disesuaikan dengan ukuran laboratorium. Setelah itu mendesain fin buritan yang digunakan dengan memperhatikan variasi parameterparameter bentuk serta sudut yang optimal. Ukuran dan posisi ini divariasikan dan diuji di Towing Tank untuk mendapatkan hasil yang optimal.

Suatu kapal cepat khususnya pada kapal cepat dengan ukuran kecil ketika dioperasikan akan mengalami kondisi berikut [6]:

a. Pada kondisi saat kapal diam dan bergerak pada kecepatan rendah, kapal cepat (planning boat) tersebut memiliki sifat sebagai layaknya lambung displasemen (Displacement Hull). Pada kondisi ini keseluruhan gaya angkat (lift) yang bekerja pada lambung berasal dari gaya apung (Bouyant forces).

b. Sebagaimana kecepatan yang meningkat, akan berdampak pada pada koefisien kecepatan yang merupakan fungsi dari lebar rata rata kapal dan kecepatan serta percepatan grafitasi. Pada saat kapal berada pada nilai koefisien kecepatan mencapai 0,5 , akan terjadi penurunan resultan gaya hidrodinamik. Bila dibandingkan dengan gaya statis murni dikaitkan dengan letak tinggi sarat dan trim kapal.

c. Pada koefisien kecepatan antara 0,5 hingga 1,5 pengaruh dinamik menghasilkan nilai tambah yang positif terhadap gaya angkat (lift), meskipun pada sebagian besar kasus, tidak terjadi kenaikan yang signifikan pada pusat grafitasi atau kenaikan pada bagian depan haluan.

d. Pada koefisien kecepatan yang lebih besar dari 1,5, suatu kapal cepat akan memiliki gaya angkat dinamik yang akan menghasilkan kenaikan yang signifikan pada pusat grafitasi,trim, dan semakin meningginya

Selain itu pada kapal cepat bila dilihat dari bentuk konstruksi desainnya memiliki sudut deadrise (angle of deadrise). Menurut referensi [6] bila gaya angkat mendekati nol, maka demikian pula sudut trim yang dibentuk, juga akan mendekati nol. Sehingga sudut trim memiliki fungsi yang serupa dengan sudut serang pada teori hidrodinammik. Lebih jauh bila gaya angkat menurun secara linear, maka akan meningkatkan sudut deadrise. Sehingga dapat diketahui bahwa sudut deadrise memiliki hubungan langsung dengan gaya angkat (lift). Pada Gambar 3, ditunjukkan letak dari sudut deadrise $(\beta)$ suatu kapal cepat

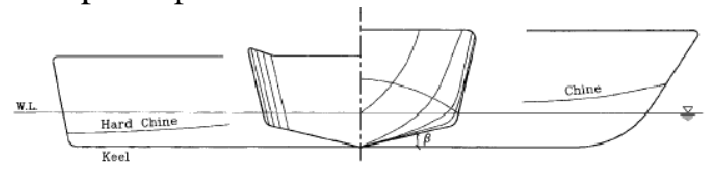

Gambar 1. Letak sudut deadrise $(\beta)$ pada suatu kapal cepat [6]

Perhitungan ini menggunakan metode Savitsky [7]. Metode ini cocok diaplikasikan pada kapal cepat terutama pada kapal cepat bentuk hard chine, perhitungannya dilakukan dengan menggunakan Froude number.

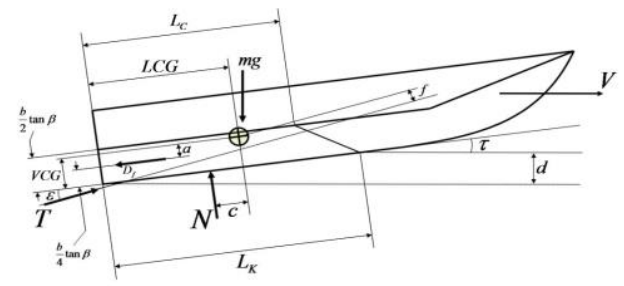

Gambar 2. Kapal saat planing hull [7] 


$$
\begin{aligned}
& \mathrm{N} \cos \tau+\mathrm{T} \sin (\tau+\varepsilon)-\mathrm{mg}-\mathrm{D}_{\mathrm{f}} \sin \tau=0 \ldots . .(1) \\
& \mathrm{T} \cos (\tau+\varepsilon)-\mathrm{N} \sin \tau-\mathrm{D}_{\mathrm{f}} \cos \tau=0 \ldots \ldots \ldots(2) \\
& \mathrm{CG} \quad: \mathrm{N} . \mathrm{c}+\mathrm{D}_{\mathrm{f} . \mathrm{a}}-\mathrm{T} . \mathrm{f}=0
\end{aligned}
$$

Kapal cepat pada saat beroperasi, mulai dari kecepatan (V) 0 knot sampai dengan kecepatan tinggi (kecepatan maksimum) dapat di lihat akan melampaui tiga tahapan (fase) kecepatan sebagai berikut [7] :

\section{a. Fase displasemen $(0,0<$ Fn $<0,6)$}

Kapal-kapal komersial besar hampir selalu berlayar pada fase ini, dimana berat kapal seluruhnya disangga oleh gaya angkat (buoyancy). Kapal yang berlayar dengan kecepatan cukup rendah $(\mathrm{Fn}<0,3)$ tidak akan mengalami perubahan trim ataupun penurunan titik berat (VCG) yang berarti. Dengan naiknya kecepatan $(\mathrm{Fn})$ perubahan tersebut mulai timbul. Perubahan ini terjadi akibat naiknya aliran karena bertambah terbenamnya kapal, yang selanjutnya sesuai Hukum Bernoulli, akan berakibat pada penurunan tekanan di bawah kapal bagian buritan dan kenaikan tekanan di bawah haluan kapal.

\section{b. Fase pre-planing $(0,6<$ Fn $<1,2)$}

Pada fase pre-planing berat kapal akan disangga lebih banyak oleh gaya angkat hidrodinamik. Gaya angkat hidrodinamik ini timbul karena adanya deviasi aliran di sekitar dasar kapal bagian buritan, sehingga mengakibatkan kapal trim. Dari berbagai pengukuran tes model didapat bahwa pada fase ini titik berat kapal akan naik. Pada sekitar $F n=0.6$, VCG mencapai ketinggian yang sama dengan pada saat $\mathrm{V}=0$ knot dan selanjutnya VCG terus naik sampai kecepatan karakteristik $F n=1,2$ dicapai. Dari kecepatan $\mathrm{v}=0$ knot sampai dengan $\mathrm{Fn}=0,9$ haluan kapal akan terus naik ke arah permukaan, sedangkan buritanya akan berangsur-angsur terbenam. Pada sekitar 0,9 < Fn <1,2 buritan kapal akan mulai naik lagi, tetapi tidak begitu besar sampai dengan munculnya haluan. Dengan demikian trim akan tetap naik sampai dengan $F n=1,2$ dicapai

\section{c. Fase planing $(\mathbf{F n}>1,2)$}

Fase planning dapat ditandai dengan kondisi dimana hampir seluruh berat kapal disangga oleh gaya angkat hidrodinamik, dan hanya sebagian kecil berat kapal yang bertumpu pada gaya hidrostatik yang juga kecil. Meskipun kapal hampir seluruhnya meluncur di permukaan air, dan permukaan basahnya menjadi sangat kecil demikian juga trim kapal mulai menurun dibandingkan dengan pada fase pre-planing, tetapi tekanan hidrodinamik menjadi sangat besar sebagai akibat kecepatan tinggi yang diperoleh dari gaya dorong propeller. Pada fase planing, bagian kapal yang terbenam sangat kecil, sehingga gelombang yang terbentuk hampir hilang sama sekali.

Bentuk planing hull paling sederhana adalah bidang datar yang diilustrasikan pada gambar 3. Pengaruh penting dari aliran adalah tinggi water level permukaan air tenang sebagai akibat dari planing. Akibatnya panjang permukaan basah yang dinamis ( L ) lebih besar dari pada yang terendam ( $\mathrm{Li}$ ). Kedua panjang ini berbeda dengan panjang stasioner (Lo). Leading edge dari permukaan basah secara nominal didefinisikan oleh lokasi spray-root line [8]. Kelengkungan permukaan biasanya diabaikan dalam perhitungan.

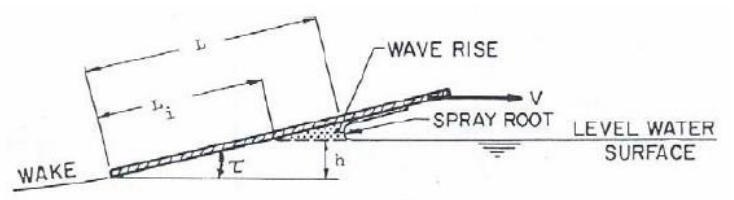

Gambar 3. Geometri sederhana dari permukaan planning [8]

\section{HASIL DAN PEMBAHASAN}

Transportasi jarak dekat di daerah Maluku pada umumnya menggunakan kapal cepat seperti diperlihatkan pada gambar 4. Rute yang dilewati yaitu rute Ambon-Wayame, Ambon-Kotajawa, Tulehu-Desa-desa di pulau Haruku, Tulehu-Haria, Tulehu-Amet (pulau Nusalaut). Rata-rata kapal cepat yang beroperasi mempunyai dua konfigurasi ukuran panjang 7,45 meter dan 4 meter. Jumlah penumpang yang diangkut adalah 20 orang, selain itu untuk kapal cepat kecil daya angkutnya adalah 6 orang. Untuk penelitian ini dikhususkan untuk kapal-kapal dengan ukuran 7,45 m. Pengoperasian kapal pada kecepatan tinggi, dengan jumlah penumpang yang kurang, kapal mengalami trim butitan yang sangat besar sehingga dapat mengganggu penglihatan dari jurumudi. Selain itu pada kondisi tersebut jika pada kondisi gelombang maka akan terjadi hentakan, maupun dapat menyebabklan capzasing yang dapat menyebabkan keselamatan dari kapal tersebut dapat diganggu, baik untuk kapal itu sendiri maupun untuk penumpang.

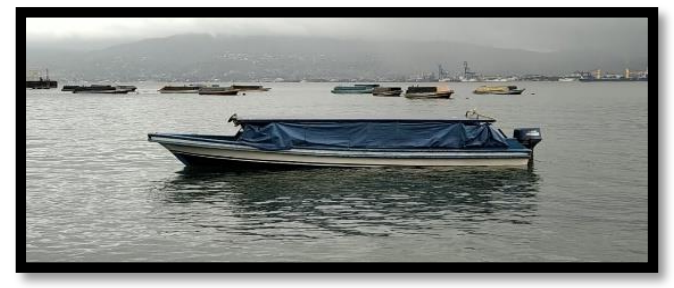

Gambar 4. Kapal cepat yang beroperasi di Teluk Ambon 
Dari data kapal yang telah dibangun yang beroperasi di ambon dan sekitarnya, diperoleh ukuran pokok kapal untuk panjang dilakukan dengan menggunakan optimisasi, dengan menggunakan database dari kapal-kapal yang melayari. Selanjutnya dari ukuran panjang tersebut sebagai acuan diperoleh lebar, panjang gharis air dan ukuran serta koefisien bentuk lainnya. Koefisien bentuk didasarkan dengan menggunakan pendekatan empiris dari data statistik. Serta pengecekan deplasemen kapal yang antara deplasement ukuran pokok dan komponen berat atau dengan kata lain penjumlahan DWT dan LWT. Hasil analisanya dapat ditentukan demikian :

- Panjang Kapal (LOA) : 7,45 m

- Panjang Garis Air : : 7,068 m

- Lebar Kapal : $1,513 \mathrm{~m}$

- Tinggi geladak $: 1,15 \mathrm{~m}$

- Tinggi Sarat : $0,4 \mathrm{~m}$

- Deplasemen : 1,925 Ton

- Koefisen blok : :0,543

- Koefisien Water line : 0,821

- Koefisien mid ship : 0,74

- Koefisen Prismatik : 0,736

- LCB : 3,237 m dari aft

Berdasarkan data diatas dibuat model dengan skala $1: 100$, sehingga memperoleh ukuran model sebagai berikut :

- Panjang utama kapal (Loa) : $0.74 \mathrm{~m}$

- Panjang garis air (LWL) $: 0.70 \mathrm{~m}$

- Lebar lambung kapal (B) : $0.15 \mathrm{~m}$

- Tinggi geladak $(\mathrm{H}) \quad: 0.11 \mathrm{~m}$

- Tinggi sarat (T) : $0.04 \mathrm{~m}$

- Desplasemen : 0.19

- Koefisien blok $(\mathrm{Cb}) \quad$ : 0.05

- coefisien water line $\quad: 0.08$

- Koefisien mid ship $\quad: 0.074$

- Koefisien prismatic : 0.073

Analisa ukuran pokok dan koefisien bentuk yang diperoleh pada proses desain kapal yang selanjutnya dilakukan penggambaran rencana garis. Dengan menggunakan luas bidang gading dan luas bidang garis air konstruktif, dan pengecekan terhadap tinggi titik tekan memanjang kapal (LCB) dimana penggambaran gading dilakukan secara manual dan memperoleh gambar body plan secara manual yang merupakan dasar dari proyeksi rencana garis. Setelah itu melalui penggambaran pada program maxsurf, maka diperoleh ukuran pokok kapal sebagai terkoreksi terhadap hasil desain. Hasil yang diperoleh adalah seperti pada Gambar 5 berikut ini :

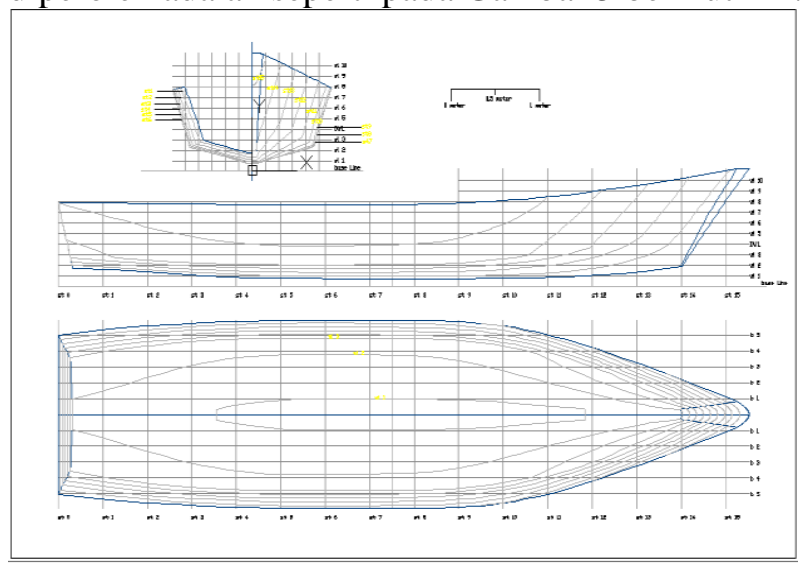

Gambar 5. Rencana garis kapal.

Hasil percobaan untuk variasi bilangan Froude (Fn) dan variasi sudut kemiringan memperoleh besar trim yang dihasilkan oleh kapal, hal itu dapat dibandingkan dengan gambar 6 sampai dengan gambar 10 berikut ini :

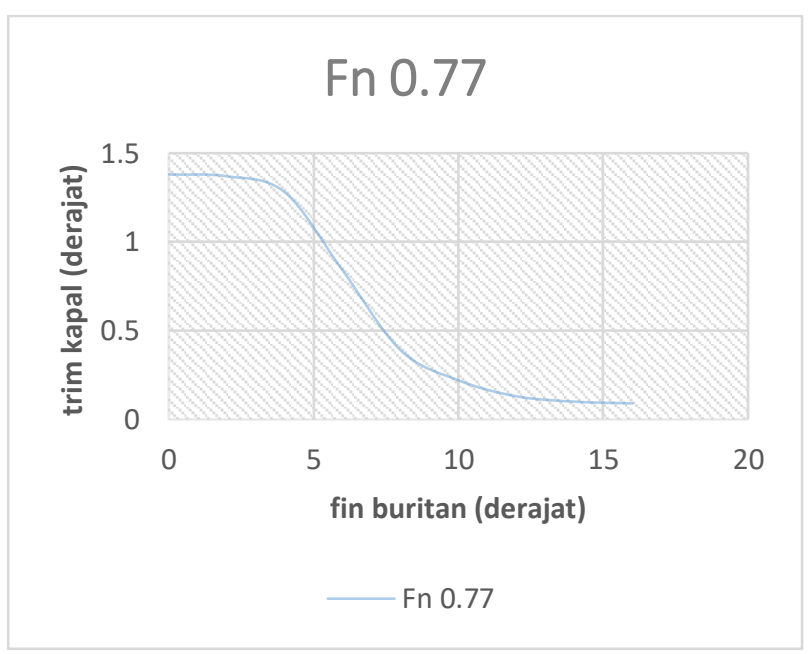

Gambar 6. Pengaruh sudut buritan terhadap trim pada $\mathrm{Fn}=0.77$

Bilangan Froude 0,77 menggambarkan bahwa pada sudut fin dibawah 4 derajat sudut trim mempunyai kecenderungan kapal berada pada 1,35 derajat, sedangkan pada sudut 4 sampai dengan 14 derajat terjadi penurunan trim kapal secara signifikan mendekati sudut 1,0 derajat dan diatas 15 derajat kondisi trim menjadi stabil kembali. Hal ini menggambarkan bahwa pada sudut diatas 15 derajat pengaruh gaya lift telah konstan, sedangkan pada sudut fin 4 sampai 15 derajat terjadi peningkatan gaya lift. 


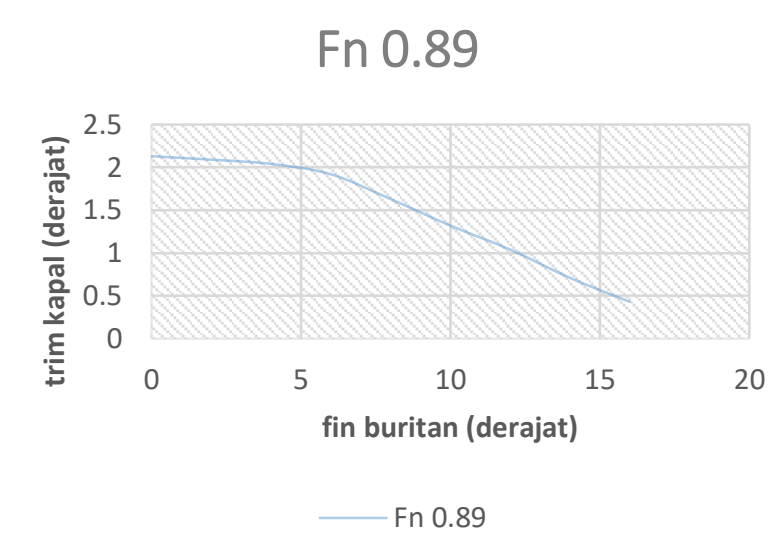

Gambar 7. Pengaruh sudut buritan terhadap trim pada $\mathrm{Fn}=0.89$

Pada Fn. 0.89 nilai grafik menunjukan terjadi perbedaan diangka 0.75 fenomena ini terjadi dikarenakan kecepatan kapal yang lebih tinggi sehingga pada sudut 0-8 derajat kapal masih berada dikondisi trim yang cukup ekstrim. Hal ini sebanding dengan peningkatan gaya lift.

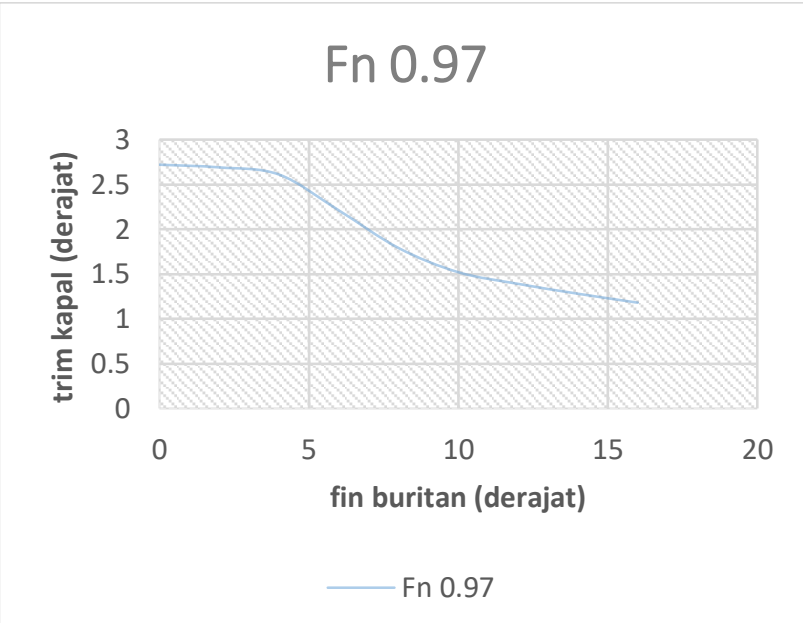

Gambar 8 Pengaruh sudut buritan terhadap trim pada $\mathrm{Fn}=0.97$

Fn 0.97 adalah batas atas nilai pengujian trim kapal, pada sudut 6 derajat kapal telah melaju dengan kondisi hampir mendekati posisi even keel dan pada sudut 8 derajat air yang masuk kedalam model telah terjadi, sampai pada sudut 16 derajat jika diperhatikan dalam pengambilan vidio luas permukaan basah sudah sangat sedikit.

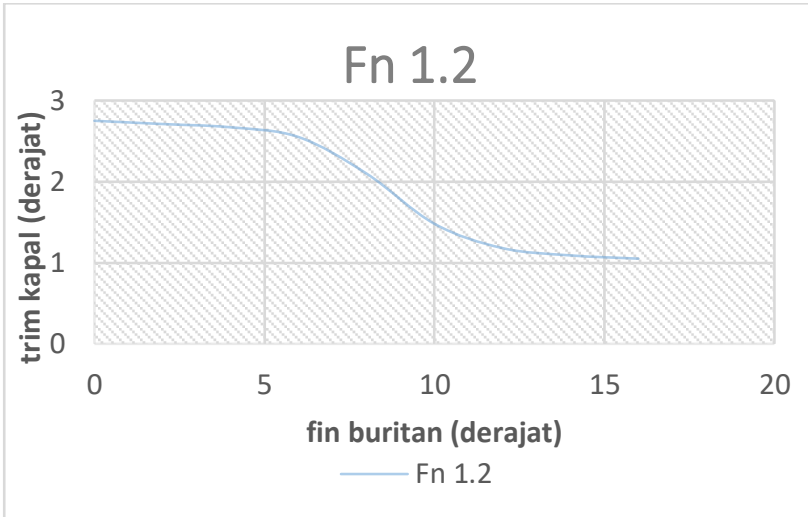

Gambar 9. Pengaruh sudut buritan terhadap trim pada $F n=1,2$

Fn 1.2 adalah Fn yang sesuai dengan kecepatan 20 knot pada speedboat di kondisi kapal kosong, fenomena trim ekstrim berada di sudut 0-6 derajat sedangkan di sudut 8 derajat kapal telah melaju dengan kondisi hampir mendekati posisi even keel dan disudut 12 derajat air yang masuk kedalam model telah terjadi di tambah kapal melaju tidak lagi dalam satu garis lurus namun zig-zag, sampai pada sudut 16 derajat jika diperhatikan dalam pengambilan vidio luas permukaan basah sudah sangat sedikit.

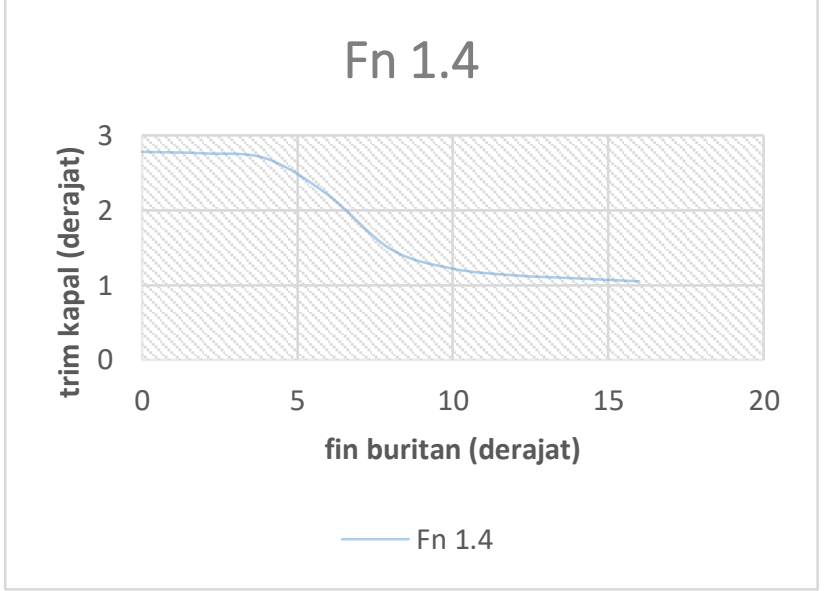

Gambar 10. Pengaruh sudut buritan terhadap trim pada $F n=1,4$

Fn 1.4 adalah batas atas nilai pengujian trim kapal, pada sudut 4 derajat kapal telah melaju dengan kondisi hampir mendekati posisi even keel dan pada sudut 8 derajat air yang masuk kedalam model telah terjadi, sampai pada sudut 16 derajat jika diperhatikan dalam pengambilan vidio luas permukaan basah sudah sangat sedikit. 


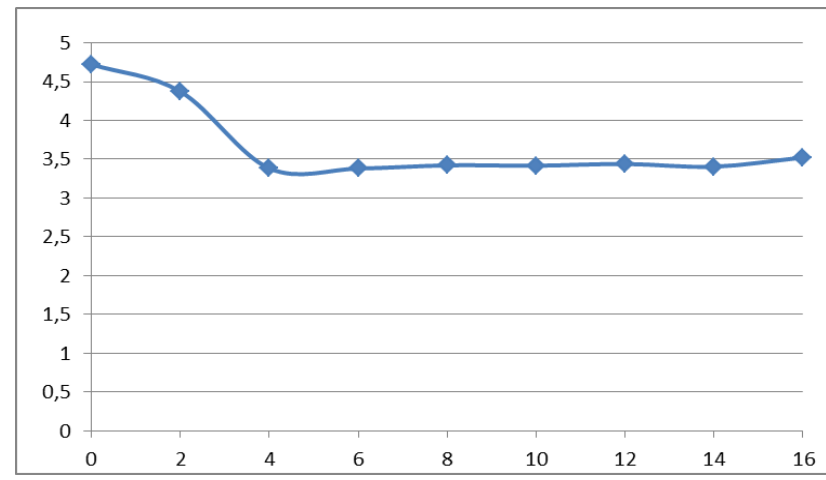

Gambar 11. Grafik hambatan dan sudut fin

Dari grafik 11 diatas, dapat dilihat bahwa nilai hambatan total kapal yang di hasilkan pada sudut $0^{0}$ sampai $4^{0}$, terjadi penurunan kurva yang signifikan nilai hambatan kapal mulai mengalami kecenderungan setelah itu trendnya terjadi peningkatan tetapi tidak signifikan, hal ini disebabkan karena pada sudut $0^{0}$ sampai $6^{0}$ sangat peningkatan hambatan sangat kecil sehingga pengaruh gaya lift sangat besar, sehingga terjadi penurunan luas permukaan basah yang berimplikasi pada besar hambatan kapal sedangkan pada sudut besar diatas $6^{0}$ pengaruh gaya drag dari fin mulai meningkat secara konstan

\section{KESIMPULAN}

Dari pembahasan diatas dapat disimpulkan bahwa:

1. Ukuran fin buritan yang efisien digunakan jika disesuaikan dengan kedudukan mesin adalah $0,36 \mathrm{~m}^{2}$ atau berukuran $0,6 \mathrm{~m} \times 0,6$

2. Sudut fin yang sesuai dengan ukuran dan kecepatan kapal-kapal speed boat yang beroperasi di Maluku dan sekitarnya yaitu sudut $6^{0}$, karena pada posisi ini konddisi kapal menjadi even keel dan mempunyai koefisien drag yang minimum sebesar 0,015

3. Kedudukan vin dalam arah vertical yaitu pada posisi 0 dengan garis transom bawah buritan, dan mempunyai lebar maksimum $0,6 \mathrm{~m}$ pada bagian sisi samping kapalPenarikan simpulan, perampatan yang meluas, dan pencetusan teori baru yang dituangkan secara mapan menjadikan artikel lebih bermakna dibandingkan dengan memuat tulisan yang berisi simpulan dangkal dan saran bahwa penelitiannya perlu dilanjutkan.

\section{DAFTAR PUSTAKA}

[1]. Sukoco., 2015“ Upaya Peningkatan Gaya Angkat Pada Model Airfoil Dengan Menggunakan
Vortex Generator”, Jurnal Teknik Vol. 5 No. 2 /Oktober, ISSN 2088 - 3676

[2]. Muchammad., 2006 "Perhitungan Gaya Drag Pada Benda Uji Pelat Persegi Datar Menggunakan Low Speed Wind Tunnel" Momentum, Vol. 2, No. 1, April 2006 : 15 - 25

[3]. Munson B.R., Young D. F., Okiishi T. H., 2003 "Fundamentals of Fluid Mechanics, Jhon Wiley $\&$ Sons, inc.

[4]. Tuncer A, Tayar G. T., and Unsan Y. 2016," Interceptor Design And Control For The High Speed Craft", GiDB DERGi Say 7

[5]. Anuar Bin Bero, May 2009 "Performance Prediction For High Speed Craft" A dissertation submitted in partial fulfillment of the requirements for the award of the degree of Master of Engineering (Marine Technology), Faculty of Mechanical Engineering Universiti Teknologi Malaysia

[6]. Savitsky D, 1964 " Hydrodynamic Design Of Planing Hull", Marine Technology, Vol I, No 1, pp 71-95, October

[7]. Savitsky D, Brown P.W., 1976 "Procedure of Hydrodynamic Evaluation Of Planing Hull In Smooth and Rought Water", Marine Technology, Vol 13, No 4, Oct 1976, pp 381-400

[8]. Irfan Syarif Arief et al., 2010 “ Analisa Pengaruh Cekungan Yang Diterapkan Pada Plat Datar terhadap Aliran Fluida Untuk Mendukung Teknologi Maritim Pendekatan CFD" Jurusan Teknik Sistem Perkapalan, Institut Teknologi Sepuluh Nopember Surabaya 